\title{
A tree-ring perspective on temporal changes in the frequency and intensity of hydroclimatic extremes in the territory of the Czech Republic since 761 AD
}

\author{
P. Dobrovolný ${ }^{1,2}$, M. Rybníček ${ }^{2,3}$, T. Koláŕr ${ }^{2,3}$, R. Brázdil ${ }^{1,2}$, M. Trnka ${ }^{2,4}$, and U. Büntgen ${ }^{2,5,6}$ \\ ${ }^{1}$ Department of Geography, Masaryk University, Brno, Czech Republic \\ ${ }^{2}$ Global Change Research Centre AS CR, Brno, Czech Republic \\ ${ }^{3}$ Department of Wood Science, Mendel University in Brno, Brno, Czech Republic \\ ${ }^{4}$ Institute of Agriculture Systems and Bioclimatology, Mendel University in Brno, Brno, Czech Republic \\ ${ }^{5}$ Swiss Federal Research Institute for Forest, Snow and Landscape, Zürich, Switzerland \\ ${ }^{6}$ Oeschger Centre for Climate Change Research, Bern, Switzerland
}

Correspondence to: P. Dobrovolný (dobro@sci.muni.cz)

Received: 25 June 2015 - Published in Clim. Past Discuss.: 16 July 2015

Accepted: 9 October 2015 - Published: 23 October 2015

\begin{abstract}
It is generally accepted that anthropogenicinduced climate change may affect the frequency and intensity of hydrological extremes, together with a variety of subsequent impacts on ecosystems and human society. Proxy records that are absolutely dated and annually resolved are indispensable to a better understanding of temporal changes in the occurrence of floods and droughts.

This contribution presents a new data set of 3194 oak (Quercus spp.) ring width samples from living trees and historical timbers, collected across the Czech Republic. A composite tree-ring width (TRW) chronology is developed that best captures the high-frequency extremes over the past 1250 years. The temporal distribution of negative and positive extremes is regular with no indication of clustering. The highest number of negative extremes was found in the 19th century, while positive extremes were most frequent in the 12 th century. The lowest number of negative and positive extremes occurred in the 18 th and 13 th centuries respectively.

Negative and positive TRW extremes were compared with the instrumental measurements back to $1805 \mathrm{AD}$, with documentary-based temperature and precipitation reconstructions from 1804 to 1500, and with documentary evidence before 1500 AD. Negative TRW extremes coincided with above-average March-May and June-August temperature means and below-average precipitation totals. Positive extremes coincided with higher summer precipitation, while
\end{abstract}

temperatures were mostly normal. Mean sea level pressure (SLP) over the European/North Atlantic sector suggested drought for the negative oak TRW extremes, whereas the positive extremes corresponded to wetter conditions overall. More consistent patterns of synoptic SLP were found for negative rather than for positive extremes. Reasons for the possible offset between the oak-based hydroclimatic extremes and their counterparts from meteorological observations and documentary evidence may be manifold and emphasize the need for multi-proxy approaches.

\section{Introduction}

Recent climate change is largely characterized by rising temperatures and spatial shifts in precipitation regimes (IPCC, 2013). Climate models predict severe changes in both the frequency and intensity of climatic extremes, such as heat waves, floods and drought spells (Fischer et al., 2013; Roth et al., 2014). There is growing evidence for amplification of the precipitation regime (Groisman et al., 2005; Knapp et al., 2008) as a consequence of increases in evaporation and changes in circulation patterns. These processes may be responsible for a higher probability that hydroclimatic extremes will occur at local to synoptic scales (Easterling et al., 2000; Huntington, 2006). 
Central Europe (CE) has experienced both disastrous floods and extreme droughts in recent decades. There is some controversy as to whether the record-breaking floods of 1997 , 2002 and 2013 (Ulbrich et al., 2003a, b; Blöschl et al., 2013), and the widespread heat waves and droughts in western Europe in 2003 (Schär et al., 2004; Ciais et al., 2005) and in western Russia in 2010 (Barriopedro et al., 2011) are directly related to recent global warming or whether they demonstrate a period of higher internal variability of the (natural) climate system itself (Schär et al., 2004; Zhang et al., 2007; Min et al., 2011; IPCC, 2013). At the same time, it is common knowledge that hydroclimatic extremes occurring on the synoptic scale are particularly critical to much of the well-being of ecological, agricultural and societal systems (Reyer et al., 2012; Rammig et al., 2015).

In CE, systematic instrumental measurements cover 200250 years at best (Jones, 2001; Auer et al., 2007; Böhm et al., 2010). The longest precipitation series from the Czech Republic (CR) originates from Brno, in the south-east of the country, and reaches back to 1803 AD (Brázdil et al., 2012). This is, however, still too short to sufficiently describe the long-term evolution of extreme events, including their return periods and changing frequencies. Hence, long-term proxy archives are essential for a better understanding of possible changes in the frequency and intensity of extreme events.

Valuable information concerning hydroclimatic extremes may be found in annually resolved and absolutely dated proxy archives, such as documentary evidence (Brázdil et al., 2005) or tree rings (Jones et al., 2009). Numerous records from living trees, historical timber, archaeological remains and sub-fossil wood have been compiled, especially for the mountainous regions, and they have been used for air temperature reconstructions (Büntgen et al., 2005, 2006) and the analysis of temperature extremes (Battipagila et al., 2010). However, a notable number of TRW chronologies exist for sites at lower elevations, largely sensitive to soil-moisture availability (Brázdil et al., 2002; Wilson et al., 2005; Büntgen et al., 2011a).

Several TRW chronologies were compiled from oaks (Quercus spp.) and their analysis confirmed that they are moisture-sensitive and suitable for hydroclimatic reconstructions (Cedro, 2007; Kern et al., 2009; Büntgen et al., 2010, 2011b; Bronisz et al., 2012; Cooper et al., 2013; Wilson et al., 2013; Rybníček et al., 2015b). There are many more hardwood TRW chronologies in Europe that have, to date, been used exclusively for dating purposes (Kolár et al., 2012) but not as climate proxy archives, mainly because of inadequate sample size (see Tegel et al., 2010 for a review).

Here, we introduce a new oak TRW chronology for the entire Czech Republic, covering the last 1250 years. We hypothesize that positive TRW extremes reflect wet springsummer conditions while negative TRW extremes can be associated with dry conditions. Instrumental measurements, proxy reconstructions and documentary evidence are used to verify this hypothesis over the last centuries to the millennium.

\section{Data and methods}

TRW measurements from a total of 3194 living, historical and sub-fossil oaks were compiled from 387 locations within the Czech Republic. Most of samples came from the two lowland regions: central Bohemia (western part of CR) and southern Moravia (eastern part of CR), where oak forests can be found. From a phytogeographical perspective, Bohemia belongs to the Hercynian region while Moravia is related to the Pannonian Basin (Chytrý et al., 2001). The two regions are characterized by relatively warm (mean annual temperature of $9-10^{\circ} \mathrm{C}$ ) and dry (annual precipitation of 450-500 mm, maximum in summer) climate conditions. Precipitation totals in these regions are significantly lower than reference evapotranspiration (Fig. 1a). Oak growth is mainly limited by water shortage and thus sensitive to hydroclimatic changes.

The spatial distribution of all samples reflects the general distribution of two oak species in CR: the English oak Quercus robur and the sessile oak $Q$. petraea, which are anatomically not distinguishable (Schoch et al., 2004). The natural habitat of the English oak is primarily concentrated in the river valleys at lower altitudes, below $500 \mathrm{~m}$ asl, whereas sessile oak reaches higher elevations. The hydroclimatic sensitivity of the two species is, however, similar (Friedrichs et al., 2009; Büntgen et al., 2010, 2011c; Tegel et al., 2010).

To build the oak chronology, 527 tree-ring series from subfossil oak trunks were processed, out of which 211 subfossil oak trunks were sampled over the past few years and 316 measurements were obtained from subfossil oak trunks found earlier in the Czech Republic. The tree-ring data of subfossil oak trunks were cross-dated using foreign chronologies (Friedrich et al., 2004; Tegel et al., 2010); in several cases $\mathrm{C} 14$ dating was also used.

Further, we used wooden archaeological finds, historic wooden constructions and living oak stands. The prevailing part of the human-touched material came from the High Middle Ages and more recent periods of settlement. In that time, oak wood was used for constructions with high mechanical loading and for constructions where material with high durability was needed. The highest proportion of oak can be found in constructions of belfries (bell holding frames), water constructions and wall enforcements. On the other hand, oak is seldom found in timber houses or ceiling constructions, where coniferous wood prevails in CR. In such constructions, oak wood is only used in areas where softwood does not occur (e.g. the Elbe River valley).

Compared to previous version of CR oak chronology (Kolár et al., 2012) additional sampling and collecting of 1036 series from living trees was done. Finally, the well- 


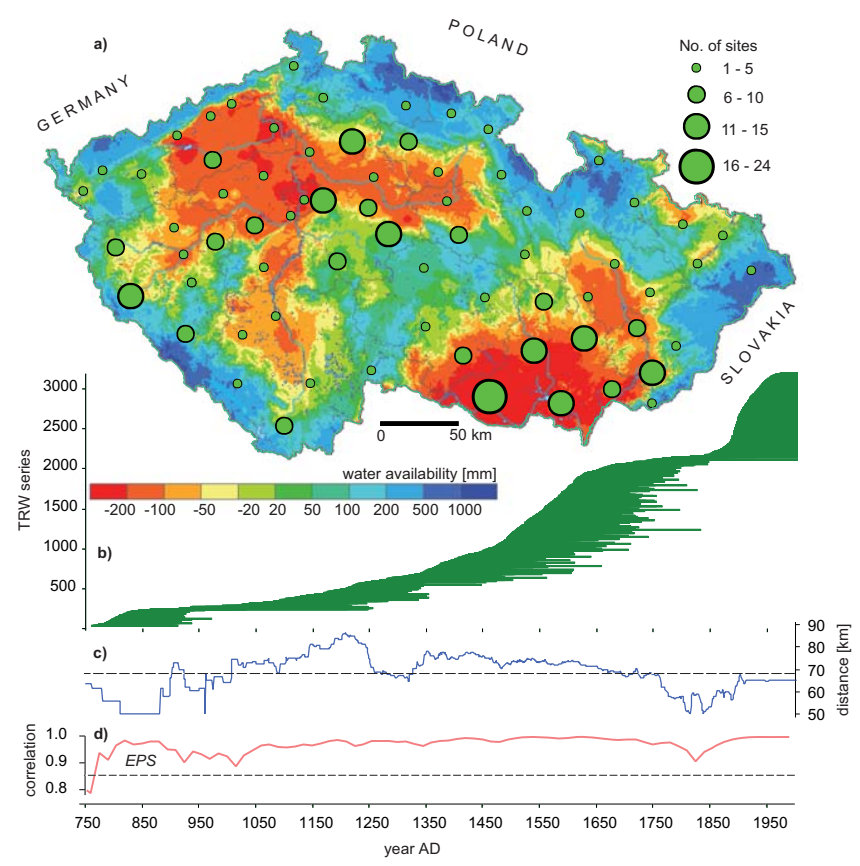

Figure 1. Spatial and temporal coverage of the Czech oak TRW chronology: (a) map of mean potential water availability estimated as the difference between annual precipitation totals and annual reference evapotranspiration in the 1981-2010 period, together with the spatial distribution of the 387 oak sampling sites, indicated as green points, with diameter expressing the number of individual sites per region. (b) Temporal distribution of the 3194 individual Czech oak TRW samples, with each horizontal line corresponding to one measurement radius. (c) Temporal changes in the mean distance between sampling sites, with the broken horizontal line indicating the mean distance between sampling sites $(69.5 \mathrm{~km})$. (d) Moving 31-year EPS statistics of the 3194 oak TRW samples, with the broken horizontal line indicating the commonly used 0.85 quality threshold.

synchronizable tree-ring series were used to create a new oak chronology for the whole territory of CR.

The new TRW data set continuously covers the period 761-2010 AD, with sample replication varying from 10 series at the beginning of the data set in the 8th century to 1028 series in the 1970 s (Fig. 1b). The spatial distribution of sampling sites is relatively homogeneous over time (Fig. 1c). Mean distance between sampling sites varies from $50 \mathrm{~km}$ at the beginning of the data set to $85 \mathrm{~km}$ in the late 12 th and early 13 th centuries.

The common signal strength among all individual oak TRW samples was addressed by moving 31-year EPS statistics (Fig. 1d), giving results that clearly exceed the required quality threshold of 0.85 (Wigley et al., 1984) back to $\sim 780$ AD. Slightly lower but statistically still robust EPS values in the second half of the 10th century and the first part of the 19 th century correspond to periods of lower sample replication.
Cubic smoothing splines with a $50 \%$ frequency response cutoff at 22, 32 and 42 years were used for standardization (de-trending) to remove "age-trends" from the raw oak TRW measurement series (SPLs; Cook and Peters, 1981). These flexible spline functions, individually fitted to each oak TRW measurement series, permit preservation of high-frequency inter-annual variability but at the same rigorously remove all information in the decadal and lower frequency domains (Battipaglia et al., 2010; Büntgen et al., 2011b). The corresponding TRW index values were calculated, either as ratios or residuals, after power-transformation (PT) between non-transformed or transformed measurements and their corresponding curve fits (Cook et al., 1995; Cook and Peters, 1997). The final oak TRW chronologies from each of the three de-trending procedures, with or without PT, were calculated as bi-weight robust means where temporal variance changes in the resulting chronologies were further stabilized with respect to fluctuations in sample size (Osborn et al., 1997). All three routinely generated chronologies from the most recent version of the ARSTAN software (Cook, 1985; Cook and Krusic, 2005), the standard, residual and ARSTAN (STD, RES, ARS) chronologies were considered. Each of the 18 slightly different chronologies was normalized, i.e. zscores with a mean of zero and a standard deviation of one were calculated over 761-2010 AD.

Negative and positive extremes were defined by years in which at least one (of a total of 18) of the transformed oak TRW chronologies exceeded the \pm 1.5 multiple of a standard deviation (SD). This threshold value was chosen to provide a sufficient number of extreme events for subsequent tree growth/climate sensitivity study in both the instrumental and pre-instrumental periods. Several parameters, including the number of extremes, the interval between two successive extreme events, and number of clusters (defined as uninterrupted periods of extreme) were used to characterize the distribution of negative and positive extremes over the 761-2010 period.

In the study of the occurrence of TRW extremes over time, it is important to establish whether a given distribution of events deviates from complete randomness or whether there is a tendency to form clusters of events. Whereas deviation from randomness may indicate causality linking the incidence of the TRW extremes with climate parameters, clustering of extremes may indicate a tendency to higher frequency and longer duration of dry and wet periods.

Our test for randomness in the temporal distribution of oak TRW extremes was based on analysis of the intervals between two adjoining extremes. Exponential distribution was employed to model these intervals, since this serves to approximate the arrival times of randomly recurring independent events. Thus, for random distribution of oak TRW extremes over time, the interval $(I)$ between these events should follow an exponential distribution. In contrast, significant deviation from such an exponential model indicates either more regular than random distribution or clustered distribu- 
tion (Villarini et al., 2011). Because exponential distribution is characterized by equality of mean and variance, these two parameters may be combined to achieve the dispersion coefficient $(\Psi)$ that is given by:

$\Psi=\frac{\operatorname{VAR}(I)}{E(I)}-1$,

where $E(I)$ and $\operatorname{VAR}(I)$ are the mean and the variance of $I$ respectively (Mailier et al., 2006). Dispersion coefficient $\Psi=0$ indicates random distribution.

Possible clustering of extremes derived from the oak TRW chronology was further tested using estimates of extremal in$\operatorname{dex}(\theta)$, an approach that compares the number of events with the number of clusters (Coles, 2001; Ferro and Segers, 2003). The interpretation of this index is straightforward: if $\theta=1$, then event occurrence is independent, whereas if $\theta<1$, then there is a tendency to cluster events.

Growth-climate response analyses were performed separately for the instrumental and pre-instrumental periods. First, the values for temperature, precipitation, drought index (only for the instrumental period), and mean SLP fields in the extreme negative/positive years identified in oak chronology were calculated. They were then compared with the values of those variables in the 1961-1990 reference period and statistical tests were used to establish significant differences. This analysis aimed to investigate whether negative/positive oak growth anomalies reflect conditions predisposing to the occurrence of dry/wet seasons.

Long and homogenized mean monthly temperature and precipitation series from CR (Brázdil et al., 2012) and monthly SPEI-1 (standard precipitation evaporation index for 1 month) drought indices (Brázdil et al., 2015) were used for comparison with the oak TRW chronology (18052010). Further, mean monthly SLP fields from the HADSLP2 database (Allan and Ansell, 2006) covering the 18502010 period were employed to describe the circulation patterns prevailing during negative and positive extremes. This is a gridded database with a spatial resolution of $5^{\circ} \times 5^{\circ}$ that covers the Atlantic-European sector $\left(30-70^{\circ} \mathrm{N} ; 30^{\circ} \mathrm{W}-\right.$ $\left.40^{\circ} \mathrm{E}\right)$.

Tree growth-climate analysis for the pre-instrumental period (AD 1500-1804) employed documentary evidencebased reconstructions of monthly and seasonal temperature means and precipitation totals (Dobrovolný et al., 2010, 2015). Mean monthly SLP fields reconstructed from various proxies by Luterbacher et al. (2002) from AD 1659 onwards were used to characterize circulation patterns in the pre-instrumental period. Regional coverage and spatial resolution of the reconstructed fields were the same as those used for the instrumental period.

Since the above quantitative reconstructions of temperature and precipitation are available only back to AD 1500 , negative and positive extremes in the oak TRW chronology before this year were compared with known documentary evidence from the CR (Brázdil and Kotyza, 1995) and also partly verified by reference to documentary evidence from other CE countries (Alexandre, 1987; Rohr, 2007; Glaser, 2008).

\section{Results}

Correlation analysis between 18 variants of Czech oak chronology and three variables (temperature, precipitation, SPEI-1) in the instrumental period demonstrated that the closest relationship occurred to March-June precipitation totals (mean correlation coefficient 0.43 ), comparable with SPEI-1 in April-July (mean correlation 0.42). Conversely, monthly and seasonal temperatures showed weak and no significant correlation. These results and the availability of precipitation reconstruction for only standard seasons dictated the use of spring (March-May) and summer (June-August) values for climate-tree growth response analysis.

\subsection{Temporal distribution of positive and negative years}

A total of 144 negative TRW extremes and 134 positive TRW extremes were found back to $761 \mathrm{AD}$. Altogether 55 negative extremes (38\%) were identified in all 18 chronologies, while only 8 years $(5 \%)$ were identified in a single chronology. The corresponding numbers for positive extremes were 38 years $(28 \%)$ and 12 years $(9 \%)$. Moreover, the number of negative extremes was on average $10 \%$ higher compared to positives; no matter what chronology variation was used.

The mean interval between two successive negative extremes was 8.8 years with a maximum of 26 years (17531779); the most frequent interval was 1 year. The corresponding numbers for mean, maximum, and modal duration of interval between the occurrences of adjacent positive extremes are 9.4, 40 (1257-1297) and 3 years, respectively. Intervals between two successive extremes modelled with exponential distribution show significant differences from this theoretical model at a confidence level of 0.05 (Fig. 2). This indicates that the occurrence of positive and negative extremes in the oak TRW chronology varies from random. The same conclusion arises from the dispersion coefficients for negative ( $\Psi=-0.7)$ and positive $(\Psi=-0.2)$ extremes. These coefficients are below zero and thus indicate more regular than random distribution.

Clusters of extremes exceeding 1 year were quite rare in oak growth. Ten cases of negative extremes occurred in 2 successive years and in two periods in 3 consecutive years (981-983 and 1636-1638). These periods may indicate tendencies for long-term drought occurrences. Eight positive extremes were identified that lasted for 2 consecutive years. Thus, comparison of number of events and number of clusters for negative (144 vs. 132) and positive (134 vs. 126) extremes results in an extremal index of $\theta=1$, indicating no significant clustering.

The temporal distributions of negative and positive extremes found in TRW oak chronology appear in Fig. 3a, b. 

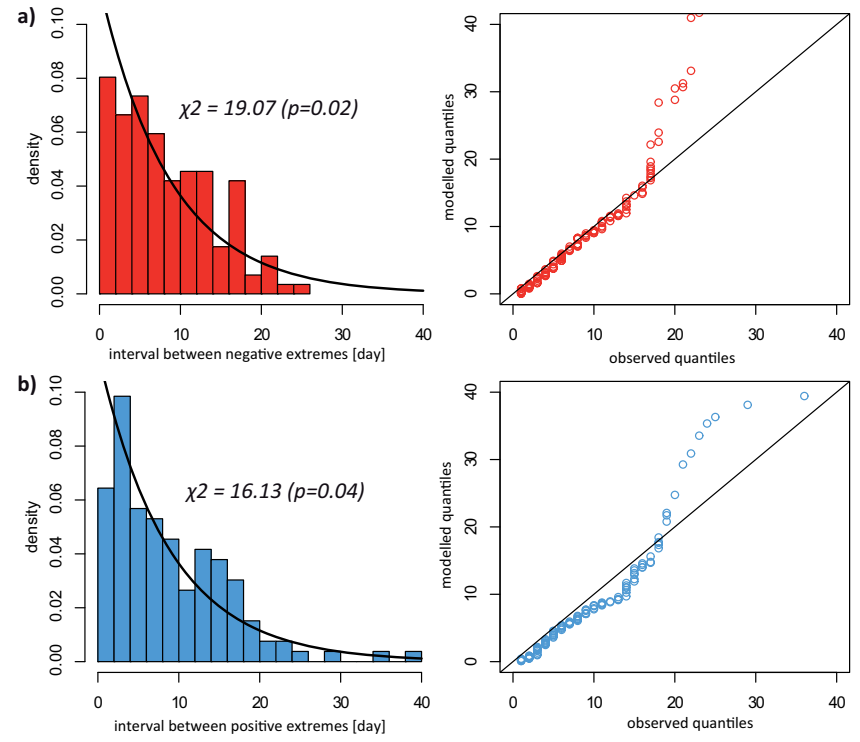

Figure 2. Intervals between successive negative (a) and positive (b) extremes from oak TRW chronology modelled by exponential distribution and completed with Chi-squared test and Q-Q plots (right).

The highest number of negative extremes was found for the 19th century (19), while positive extremes were most frequent in the 12th century (16). The lowest number of negative (8) and positive (7) extremes occurred in the 18th and 13th centuries respectively. None of the positive extremes reached 3 SD threshold, while 3 negative years $(945,1142$, and 1653) were lower than $3 \mathrm{SD}$, representing years with the most severe TRW increment reductions. The temporal distribution of negative and positive events was further addressed by a simple index of extremity, calculated as the product of standardized TRW (representing intensity of extremes) and number of extremes (representing frequency of extremes) for a 30-year moving window (Fig. 3c, d). Thus periods with larger numbers of very narrow/wide TRW are characterized by higher extremity of negative/positive events.

While temporal distributions of negative and positive extremes tend to be regular (as above, and Figs. 2 and 3a, b), the extremity index shows periods of higher values for positive extremes centred in the 12th century and at the beginning of the 18th century, separated by clearly lower extremity values, especially in the second half of the 13th century. Extremity of negative events represented by very narrow TRW was generally higher but also more variable before 1200 . After that time, a similar period of lower extremity to that indicated for positive events occurs. Recent decades may be characterized by lower extremity values for both types of extreme. Comparison of the negative and the positive extremity indices indicates that they are not in phase for a substantial part of the chronology. This means that periods of lower extremity in positive TRW events are not compensated for by higher ex- tremity in negative TRW events and vice versa. As it may be assumed that more variable climate is related to higher frequency and intensity of extreme events, these aspects of oak TRW extremity indices may be interpreted as periods of higher/lower hydro-climatic variability in central Europe.

\subsection{Climate sensitivity in the instrumental period}

A total of 26 years with negative TRW extremes were identified in the 1805-2010 period. While MAM and JJA Czech precipitation totals and SPEI-1 values were significantly below mean $(p<0.05)$, temperatures did not diverge significantly from normal patterns. Moreover, temperatures fluctuated on a broad scale in both seasons (Fig. 4). Thus negative extremes correspond to dry conditions when tree growth stress is particularly related to the shortage of available precipitation. In contrast, the climate patterns for the 23 years with positive extremes were less pronounced. Only JJA precipitation totals and SPEI-1 show the above-mean values that might indicate a surplus of moisture and favourable conditions for oak growth.

Both MAM and JJA mean SLP fields in extremely negative (positive) seasons in the instrumental period indicate circulation patterns that are highly favourable to the occurrence of dry (wet) conditions in CE (Fig. 5). For negative extremes, a statistically significant increase of SLP in a large part of Europe in spring emerged in comparison with the reference period. The positive pressure anomaly diminished somewhat in the summer months. Positive pressure anomalies signal below-mean precipitation totals and above-mean temperatures in both seasons. This corresponds to the characteristic prerequisites for drought occurrence in CE.

In spatial terms, the SLP anomalies in MAM and JJA with positive oak TRW extremes exhibit an extended region of SLP decrease running diagonally from the south-west to the north-east. In MAM this decrease is at its most pronounced over France and the western Mediterranean; in JJA the area shifts westwards to the Atlantic mid-latitudes. Conversely, a positive SLP anomaly extends over Iceland. From the analysis of above-mean oak TRWs in CE, it follows that SLP distribution is associated with zonal circulation involving more concentrated transport of air masses from the Atlantic and with abundance of precipitation.

\subsection{Climate sensitivity in the pre-instrumental period}

Distinctly low precipitation totals and above-mean MAM temperatures characterized negative TRW extremes (Fig. 6). Low precipitation totals and above-mean temperatures also appeared in JJA. However, they did not differ significantly from the reference period. On the other hand, both precipitation and temperatures showed high variability in individual years, clearly indicating that other drivers are also responsible for the most severe reductions in oak TRW increment. 


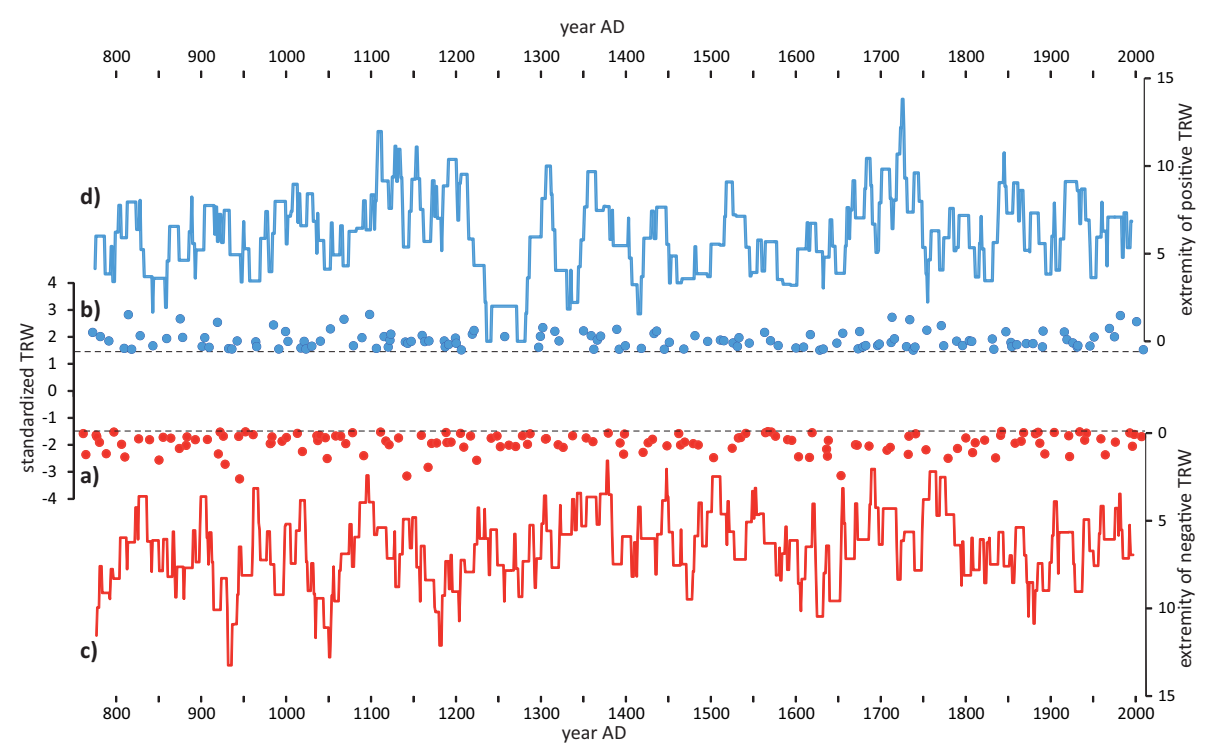

Figure 3. Negative (a) and positive (b) extremes found in the set of 18 slightly different time series of high-pass filtered TRW Czech oak chronology in the 761-2010 period; solid lines represent extremity index of negative (c) and positive (d) years calculated for a 30-year moving window (see text for details of extremity index).

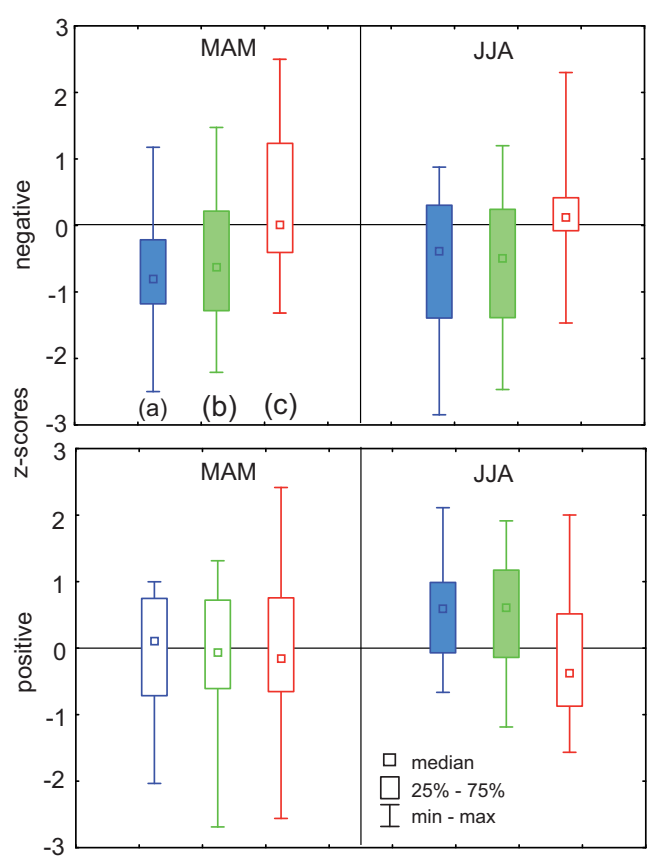

Figure 4. MAM and JJA precipitation totals (a) SPEI-1 (b) and air temperatures (c) characterizing 26 extremely negative and 23 extremely positive years found in the Czech oak chronology for the 1805-2010 period; boxes in colour mark variables that are significantly different from the 1961-1990 reference period.

A more straightforward interpretation may be offered for positive extremes (very wide oak TRW) in JJA. The mean precipitation total over 35 positive seasons is significantly higher than the reference period. Conversely, air temperature calculated for those positive seasons is significantly below the mean. In MAM, only precipitation totals were significantly below mean. Temperatures and precipitation were again highly variable in individual years.

Typical SLP spatial distribution in both types of TRW extreme (Fig. 7) shows a very similar pattern to that for the instrumental period (Fig. 5). Similarly, there is a region of distinctly higher pressure in 12 negative seasons, with the positive SLP anomaly shifting westerly over Great Britain and Ireland and the North Sea. This kind of spatial SLP pattern corresponds to blocking anticyclones bringing warm air from the south-east and low precipitation totals, with a higher probability of drought occurrence in CE. In contrast, typical SLP distribution for positive extremes shows an extended region of lower-than-normal anomalies in the mid-latitudes all over Europe. This decrease is highly significant, especially in MAM. The significant negative SLP anomaly in JJA is better localized over a region extending from the British Isles to CE.

Any description of the climate leading to oak-growth extremes before AD 1500 is inevitably restricted. Existing proxy reconstructions are either unrepresentative of CR territory or they do not refer to hydroclimatic conditions (i.e. dry or wet periods). Among the few exceptions, an MAMJJ precipitation reconstruction derived from fir TRW in southern Moravia (the south-eastern part of the CR) from AD 1376, is worth a mention (Brázdil et al., 2002). Reconstructed precipitation totals were significantly lower in negative years and significantly higher in positive years with respect to the reference period (not shown here). This indicates a consistent 

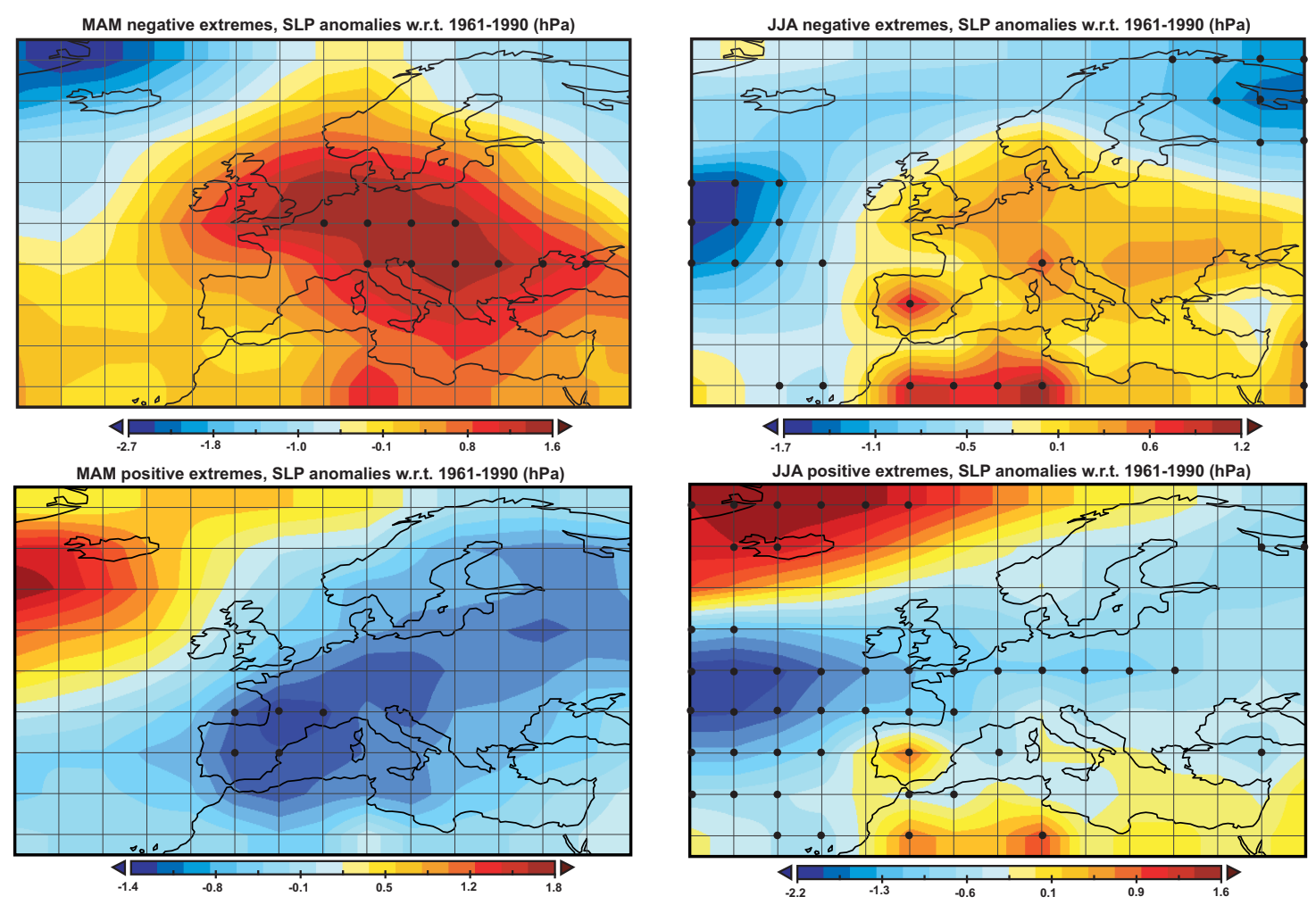

Figure 5. MAM and JJA SLP anomalies (ref. 1961-1990) for 25 extremely negative and 21 extremely positive years found in the TRW Czech oak chronology in the 1850-2010 period; black points indicate statistically significant differences $(p<0.05)$.

response of both tree species to moisture regime in the dry region of southern Moravia.

A partial verification of climate conditions in TRW extreme years before $\mathrm{AD} 1500$ may be based on existing documentary evidence from the $\mathrm{CR}$ and from the $\mathrm{CE}$ region (Table 1 ). A total of 45 extremely negative and 47 extremely positive years were identified in the Czech oak TRW chronology for the 761-1499 period. The first descriptions of extreme TRW years in documentary evidence appear as long ago as the mid-11th century. Documentary sources before AD 1500 are sporadic, so only 24 negative years and 19 positive years can be identified from available evidence. Moreover, relevant information for several extreme TRW years was found not for MAM or JJA but for the preceding winter or autumn; these aspects are discussed in the following section.

\section{Discussion}

Previous studies have analysed either the occurrence of extremes in temperature-sensitive TRW chronologies (Battipaglia et al., 2010) or extremes in moisture-sensitive TRW chronologies compiled from different tree species such as fir or pine (Opala and Mendecki, 2014; Opala, 2015). Several studies focused on negative (dry) extremes in moisture-sensitive series (Büntgen et al., 2010, 2011a).
This paper addresses extremely negative (dry) and positive (wet) years, which appeared in a hydroclimate-sensitive oak TRW chronology from the CR. Compared to Büntgen et al. (2011b), oak TRW extremes are not verified against temperature and precipitation indices derived from documentary evidence, but relate to quantitative documentary evidencebased temperature and precipitation reconstructions for the pre-instrumental period. Moreover, oak TRW extremes in the instrumental period are also here compared with the SPEI1 , combining temperature and moisture regime into a single variable.

The quality of the Czech oak TRW chronology, considered in terms of number of replications and EPS statistics, is stable over time. Well-replicated oak chronology and adequate spatial coverage of sampling sites enables detachment from the influences of local geography. Rybníček et al. (2015a) analysed the sensitivity of various oak species to climate and concluded that growth response depends more on the type of site than on oak species.

Possible differences in oak growth due to a different geography and role of environmental factors (e.g. soil types, altitude) in the western and eastern part of CR were tested as follows: two separated chronologies were composed for Bohemia and Moravia and compared over the common period 960-1826. These two chronologies are extremely similar to each other: overlapping by 867 years, the $t$ value according 
Table 1. Negative and positive years identified in oak TRW chronology for which relevant weather information was found in documentary evidence dating to before AD 1500: A87 - Alexandre (1987); BK95 - Brázdil and Kotyza (1995); BK00 - Brázdil and Kotyza (2000); B13 - Brázdil et al. (2013); G08 - Glaser (2008); R07 - Rohr (2007).

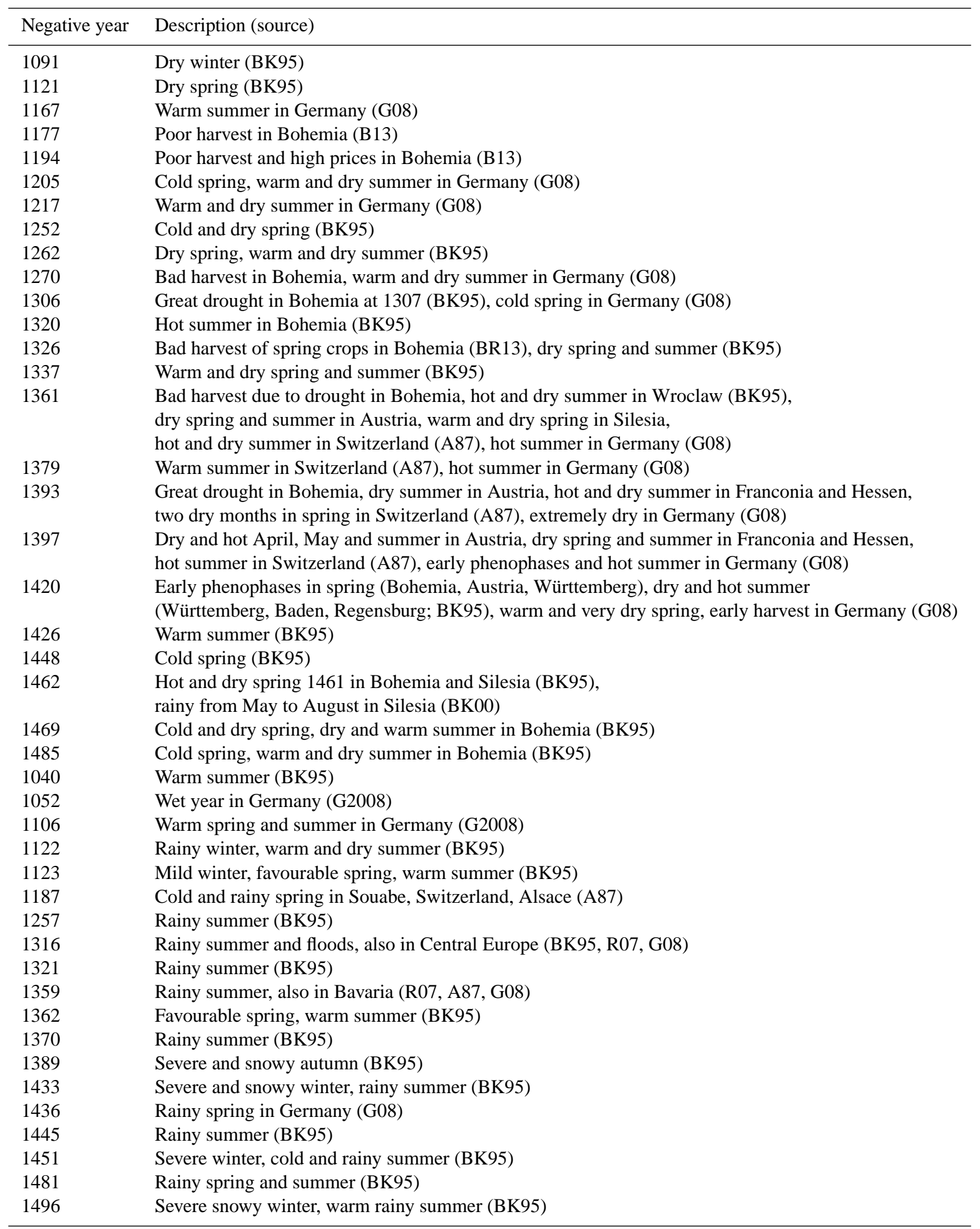




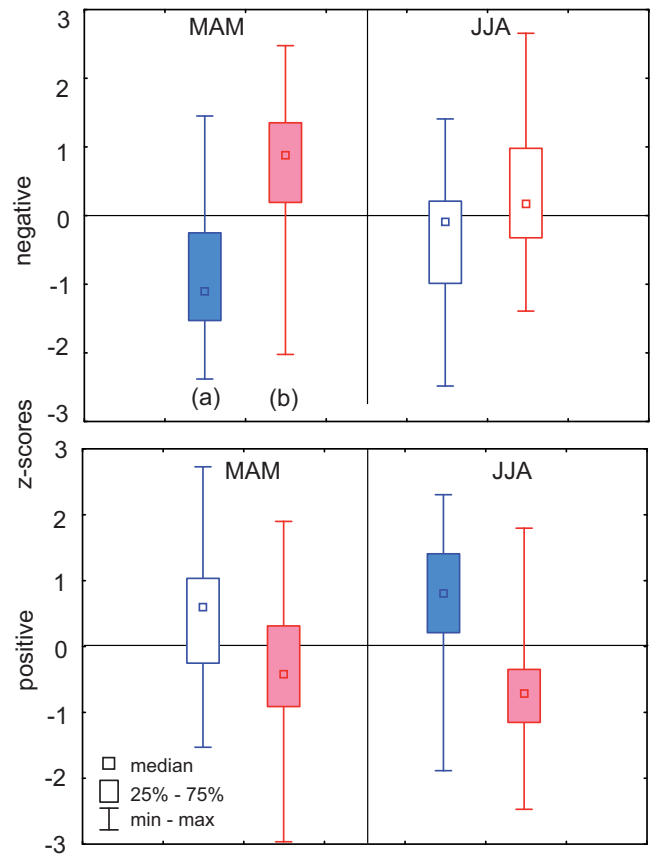

Figure 6. MAM and JJA precipitation totals (a) and air temperatures (b) characterizing 30 negative and 35 positive years found in the Czech oak chronology in the 1500-1804 period; boxes in colour indicate characteristics that are significantly different from the 1961-1990 reference period.

to Baillie and Pilcher (1973) is 19.43 and the value of Gleichlaufigkeit (Eckstein and Bauch, 1969) is $70.88 \%$ (Kolár̆ et al., 2012).

The numbers of extreme events identified indicate that there is a clear tendency towards an enhanced ability to capture negative rather than positive extremes in oak chronology. These results accord with certain previous studies (Büntgen et al., 2011b) and also with some common dendroclimatological observations (Frank et al., 2007; Battipaglia et al., 2010). More consistent results for negative extremes also arise out of analysis of documentary evidence; the percentage of negative TRW extremes confirmed from historical sources $(53 \%)$ is significantly higher compared to the positives $(40 \%)$. Moreover, direct descriptions of drought occurrence for a total of 19 years appear in various documentary sources. Descriptions of positive extreme years are intrinsically somewhat indirect, sometimes referring to temperature $(1014,1106)$, abundant snow cover in the preceding winter $(1433,1496)$ or generally "favourable" (1362) conditions. A similar picture emerges from comparison of oak TRW extremes with the 20 most negative and positive TRWbased ZIND values reconstructed from fir TRW for southern Moravia in the 1501-1932 period (Büntgen et al., 2011a). Altogether 12 negative and 10 positive extremes were found in the two chronologies.
Complete list of 144 negative and 134 positive extremes identified in Czech TRW oak chronology in the 761-2010 period is provided in Table S1 in the Supplement. Moreover, CR oak extremes were validated against hydroclimatic extremes identified in seven various data sets compiled from documentary evidence, tree rings and instrumental measurements from Central Europe. Besides proxy reconstructions from the territory of CR (Brázdil et al., 2002; Büntgen, 2011a; Dobrovoný et al., 2015) other data sets from Central Europe were used for comparison. Several TRW hydroclimate reconstructions exist for central and southern Poland - the territory that has a precipitation and/or moisture regime comparable to CR. Cross-checking of CR oak extremes against two Scots pine TRW chronologies sensitive to hydroclimate from Upper Silesia and southern Poland in the 1770-2010 period (Opala and Mendecki, 2014) and in the 1568-2010 period (Opala, 2015) was done.

As our new oak chronology covers much longer period of time compared to other data sets, reasonable validation may not be done until the beginning of the 14th century. Even if this type of direct validation may be biased due to several factors (e.g. length of common period, different way of the negative/positive year definition, different species of treering chronologies and their different sensitivity to hydroclimate), we were able to confirm $67 \%$ of negative and $56 \%$ of positive extreme years found in CR oak chronology from the beginning of the 14th century. Over the common period 1770-1932 we found an agreement for 89 and $57 \%$ negative/positive extremes respectively.

Although the response of oak TRW to the main climate variables in $\mathrm{CE}$ is particularly interpretable for negative (dry) extremes, there exist numerous departures from the general scheme outlined in the previous section when one turns to individual years. The main obstacle arises out of the fact that the climate is not the only driver of tree growth (Birks et al., 2010). Moreover, our ability to analyse climate-tree growth relations is restricted to only a limited number of climate variables. Of the three variables used in this contribution, only MAM and JJA precipitation and SPEI-1 demonstrate significant correlations to oak TRWs in the instrumental period, but the degree of explained variance is rather low (about 18-20\%). There is no significant relation between oak TRW and air temperature. Two other problems may further complicate matters:

i. Tree growth-climate relations occasionally exhibit a degree of temporal instability and reduced sensitivity of trees to climate. This feature has frequently been discussed, especially in terms of TRW-temperature relations (Frank et al., 2007; D’Arrigo et al., 2008). However, it also appears in TRW-hydroclimate analyses. Thus, for example, Büntgen et al. (2011a) discussed reduced sensitivity of fir TRWs to drought in southern Moravia. Authors - among other stressors - mentioned air pollution as a possible factor that may be responsible 

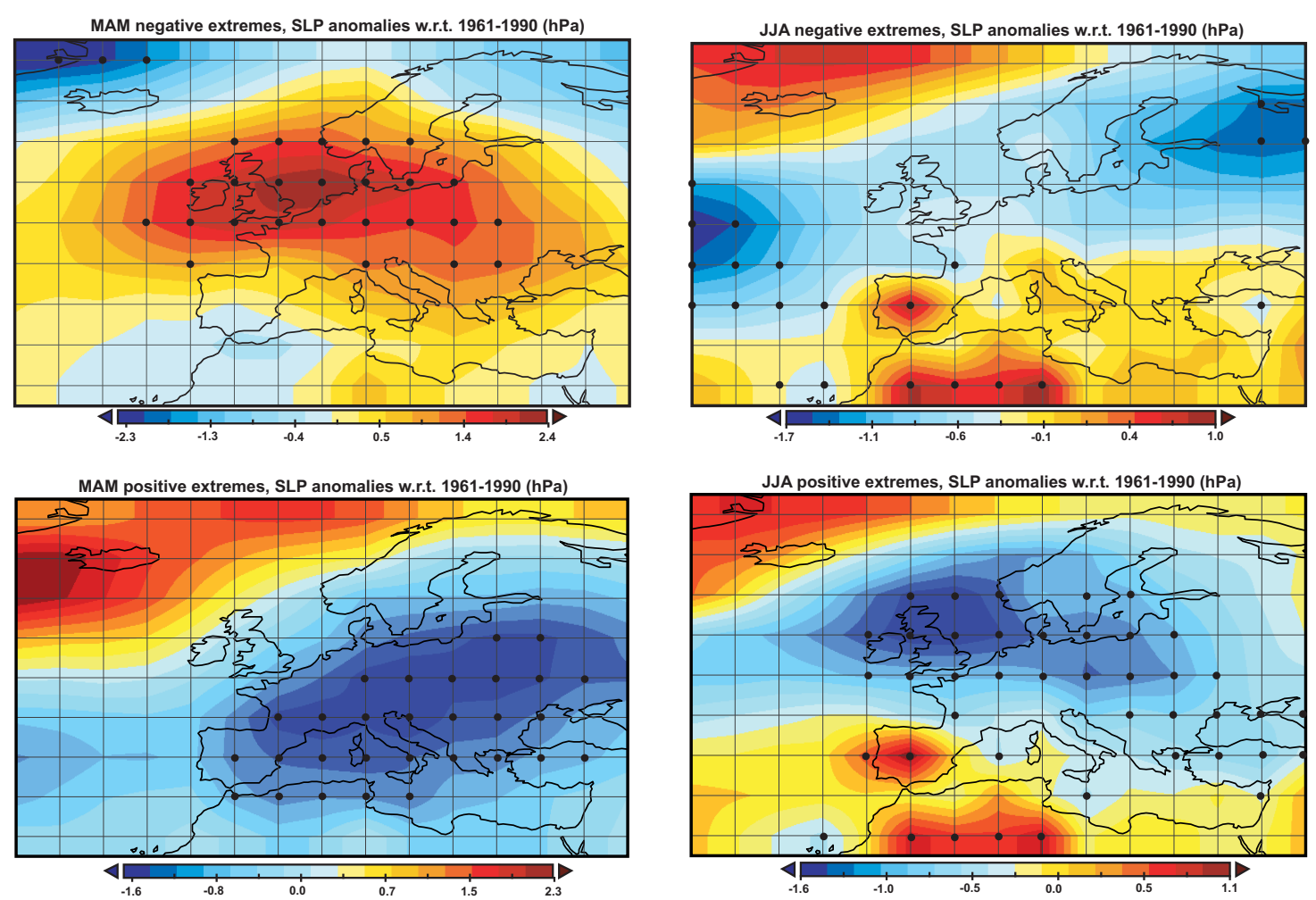

Figure 7. MAM and JJA SLP anomalies (ref. 1961-1990) for 12 negative and 19 positive extreme years found in the Czech oak TRW chronology in the 1659-1804 period; black points indicate statistically significant differences $(p<0.05)$.

for temporal instability in the growth-climate relationship. Significant tree growth reduction of conifers due to high $\mathrm{SO}_{2}$ concentrations in Northern Bohemia was already proved (Rydval and Wilson, 2012). Thus one can assume that the gradual increase of air pollution in Central Europe since the 19th century was the factor also affecting oak TRW growth-climate relationship. In the current study, correlations between precipitation totals and oak TRW are also much higher for the 19th century compared with the 20th century.

ii. The response of trees to climatic extremes may be even more complicated. Severe droughts or exceptionally humid seasons may induce negative/positive responses in tree growth that may be highly non-linear after a certain threshold (Morin et al., 2010; Gea-Izquierdo et al., 2011; Loyd et al., 2013). The roles of certain factors may vary in their impacts on the climate-tree growth process. For example, Jolly et al. (2005) found variations in vegetation growth response in the extremely warm year of 2003 in the Alps. There was a positive effect on trees at high elevations while growth suppression as a consequence of extremely high summer temperatures and drought occurrence occurred at lower altitudes.
Of the three the most extreme negative years found in our oak TRW chronology, the first two (945 and 1142) are not confirmed by documentary evidence (sparse, as indicated above, before AD 1200). Only for the 1653 year does relevant information exist in documentary data. This year was dry before 1 June in the Czech Lands and an extremely warm, dry May has been derived for Switzerland (Pfister, 1999). Moreover, 1653 was also identified as extremely dry in the CE TRW chronologies analysed by Büntgen et al. (2011b).

Seasonality may be another source of uncertainty in extreme climate and/or tree growth responses. Temperature and moisture distribution during the vegetation period, and the onset, duration and intensity of cold/warm (wet/dry) spells are factors that may significantly influence vegetation (Jones et al., 2009; Birks et al., 2010). Different seasonality may be a factor explaining the occurrence of negative oak TRW extremes in a year following one with extreme weather patterns documented by documentary sources. For example, 1462 was identified as a year with severe TRW increment reduction, but Czech documentary sources had already reported a hot, dry spring in 1461. Another example of lagged response is mentioned by Pfister (1999) and Brázdil et al. (2013), when the hot, dry year of 1719 was followed by narrow fir TRW in 1720 (Büntgen et al., 2011a). It is worth noting that neither of these 2 years was identified as a negative year in Czech oak TRW chronology. 
Such disagreement is particularly remarkable for 1540 , classified by Wetter and Pfister (2013), on the basis of numerous documentary sources, as one of the hottest and driest years for the previous 500 years in a substantial part of Europe. The Czech oak TRW chronology classifies 1541 as a negative extreme. It seems highly probable from combining information from documentary sources and tree rings that the extremely warm and dry weather of 1540 is at least partly "hidden" in some tree-ring data sets dating to 1541 and/or 1542. All these uncertainties lead to the conclusion that the absolute intensity of such extremes is difficult to estimate, at best, to evaluate from any type of proxy record.

These examples stress the relevance of a multi-proxy approach to the analysis of past climate extremes, and also in climate reconstructions (Trachsel et al., 2012). Documentary evidence proved to be a valuable source of information for the verification of negative and positive oak TRW extremes in the pre-instrumental period in this study. For example, such well-known dry extremes as those in 1616, 1636 and 1976, described in numerous documentary sources (Brázdil et al., 2012), were also identified in the Czech oak TRW chronology. In addition to 1636, the following 2 years, 1637 and 1638, appeared as negatives in the Czech oak TRW chronology. This may indicate the occurrence of drought of longer duration, but may also be related to the seasonality problem discussed above.

However, some comparisons of TRW extremes and documentary evidence are largely unambiguous, particularly for positive extremes and temperature regime, since the effects of air temperature on tree growth and TRW increments may be either positive or negative, depending on moisture regime. For example, after the favourable spring of 1362, a warm summer could contribute to above-mean oak TRW increments. Conversely, in 1451 wider TRWs were formed in the cold and rainy summer that came after the severe winter of 1450/1451 (Brázdil and Kotyza, 1995). Documentary sources mentioned warm summers in 5 years with positive oak TRW increments. This is partly in contradiction to the results presented in Fig. 7, where positive oak TRW increments were characterized by below-mean temperatures. However, as shown in Fig. 5 for the instrumental period, MAM and JJA temperatures do not differ significantly from normal conditions in years with positive oak TRW extremes and they are quite widely variable. The second reason for such a contradiction may be associated with the character of documentary evidence. While TRW measurements are provided on an absolute scale, narrative sources are interpreted as relative departures from normal conditions (Brázdil et al., 2005). Thus a reference to a "warm summer" does not necessarily constitute unequivocal (if circumstantial) evidence of drought and the resulting impact of temperature regime on tree growth may be significantly modified by moisture regime and precipitation distribution (Büntgen et al., 2011b).

\section{Conclusions}

A well-replicated, 1250-year-long oak TRW chronology was compiled and used to define positive (wet) and negative (dry) extremes using a simple threshold approach. Chronology standardization was based on several de-trending techniques, only slightly different, to ensure robustness in the selection of extreme years. Distribution of extremes over time did not indicate any kind of clustering, but a higher number of negative extremes compared to positive years emerged.

Homogenized long-term series of air temperature, precipitation totals and SPEI from the instrumental period provide consistent physical explanation of extremely dry seasons compared to extremely wet seasons. The same was found for the pre-instrumental period after AD 1500, for which comparison was based on existing temperature and precipitation reconstructions relevant to the territory of the Czech Republic.

We found that distinctly above-mean MAM and JJA temperatures and below-mean precipitation totals characterize years of TRW negative extremes. The distribution of SLP in those years typically reveals patterns that are favourable to a higher probability of drought occurrence in CE. Years with positive extremes in oak TRW chronology are characterized by above-mean precipitation totals, especially in summer, with temperatures largely close to normal.

However, climate in years with extreme oak TRWs show high variability. In particular, direct comparisons of individual TRW extreme years with existing documentary evidence in the pre-instrumental period reveal the complexity of the problem, as some extremes identified in the oak TRW chronology were not confirmed by the documentary sources and vice versa. Existing differences can be related to the fact that the various proxies may have problems recording real intensity (in the sense of absolute values) or duration of extreme events due to, for example, non-linear responses of proxy data to climate drivers or to seasonality shifts.

\section{The Supplement related to this article is available online at doi:10.5194/cp-11-1453-2015-supplement.}

Acknowledgements. This work took place under the aegis of project no. 13-04291S "Spring-summer hydroclimate reconstruction of the past millennium for the Czech Republic using oak standard chronology", project no. 13-19831S "Hydrometeorological extremes in Southern Moravia derived from documentary evidence" and project no. P209/11/0956 supported by Czech Science Foundation. The authors were also supported by the project OP VK CZ.1.07/2.3.00/20.0248 (Ministry of Education, Youth and Sports) and National Sustainability Program I (NPU I), grant no. LO1415. We would like to thank Tony Long (Svinošice) for English-language correction. 
Edited by: J. Luterbacher

\section{References}

Alexandre, P.: Le climat en Europe au Moyen Age, Contribution à l'historie des variations climatiques de 1000 à 1425, d'après les sources narratives de l'Europe occidentale, École des Hautes Études en Sciences Sociales, Paris, 825 pp., 1987.

Allan, R. and Ansell, T.: A new globally complete monthly historical gridded mean sea level pressure dataset (HadSLP2): 18502004, J. Climate, 19, 5816-5842, 2006.

Auer, I., Böhm, R., Jurkovic, A., Lipa, W., Orlik, A., Potzmann, R., Schöner, W., Ungersböck, M., Matulla, C., Briffa, K., Jones, P., Efthymiadis, D., Brunetti, M., Nanni, T., Maugeri, M., Mercalli, L., Mestre, O., Moisselin, J. M., Begert, M., MüllerWestermeier, G., Kveton, V., Bochnicek, O., Stastny, P., Lapin, M., Szalai, S., Szentimrey, T., Cegnar, T., Dolinar, M., GajicCapka, M., Zaninovic, K., Majstorovic, Z., and Nieplova, E.: HISTALP - historical instrumental climatological surface time series of the Greater Alpine Region, Int. J. Climatol., 27, 17-46, doi:10.1002/joc.1377, 2007.

Baillie, M. G. L. and Pilcher, J. R.: A simple cross-dating program for tree-ring research, Tree-Ring Bulletin, 33, 7-14, 1973.

Battipaglia, G., Frank, D. C., Büntgen, U., Dobrovolny, P., Brazdil, R., Pfister, C., and Esper, J.: Five centuries of Central European temperature extremes reconstructed from tree-ring density and documentary evidence, Global Planet. Change, 72, 182-191, 2010.

Barriopedro, D., Fischer, E. M., Luterbacher, J., Trigo, R. M., and García-Herrera, R.: The hot summer of 2010: redrawing the temperature record map of Europe, Science, 332, 220-224, 2011.

Blöschl, G., Nester, T., Komma, J., Parajka, J., and Perdigão, R. A. P.: The June 2013 flood in the Upper Danube Basin, and comparisons with the 2002, 1954 and 1899 floods, Hydrol. Earth Syst. Sci., 17, 5197-5212, doi:10.5194/hess-17-5197-2013, 2013.

Birks, H. J. B., Heiri, O., Seppä, H., and Bjune, A. E.: Strengths and Weaknesses of Quantitative Climate Reconstructions Based on Late-Quaternary Biological Proxies, The Open Ecology Journal, 3, 68-110, 2010.

Brázdil, R. and Kotyza, O.: History of Weather and Climate in the Czech Lands I (Period 1000-1500), Zürcher Geographische Schriften, 62, Zürich, 260 pp., 1995.

Brázdil, R. and Kotyza, O.: History of Weather and Climate in the Czech Lands IV. Utilisation of Economic Sources for the Study of Climate Fluctuation at Louny and Surroundings in the Fifteenth-Seventeenth Centuries, Masaryk University, Brno, 350 pp., 2000.

Brázdil, R., Štěpánková, P., Kyncl, T., and Kyncl, J.: Fir tree-ring reconstruction of March-July precipitation in southern Moravia (Czech Republic), 1376-1996, Clim. Res., 20, 223-239, 2002.

Brázdil, R., Pfister, C., Wanner, H., von Storch, H., and Luterbacher, J.: Historical climatology in Europe - the state of the art, Clim. Change, 70, 363-430, doi:10.1007/s10584-005-5924-1, 2005.

Brázdil, R., Zahradníček, P., Pišoft, P., Štěpánek, P., Bělínová, M., and Dobrovolný, P.: Temperature and precipitation fluctuations in the Czech Republic during the period of instrumental measurements, Theor. Appl. Climatol., 110, 17-34, doi:10.1007/s00704012-0604-3, 2012.
Brázdil, R., Dobrovolný, P., Trnka, M., Kotyza, O., Reznícková, L., Valášek, H., Zahradnícek, P., and Štepánek, P.: Droughts in the Czech Lands, 1090-2012 AD, Clim. Past, 9, 1985-2002, doi:10.5194/cp-9-1985-2013, 2013.

Brázdil, R., Trnka, M., Mikšovský, J., Řezníčková, L., and Dobrovolný, P.: Spring-summer droughts in the Czech Land in 1805-2012 and their forcings, Int. J. Climatol., 35, 1405-1421, doi:10.1002/joc.4065, 2015.

Bronisz, A., Biak, S., Bronisz, K., and Zasada, M.: Climate influence on radial increment of oak (Quercus SP.) in central Poland, Geochronometria, 39, 276-284, doi:10.2478/s13386-012-00117, 2012.

Böhm, R., Jones, P. D., Hiebl, J., Brunetti, M., Frank, D., and Maugeri, M.: The early instrumental warm-bias: a solution for long central European temperatures series 1760-2007, Clim. Change, 101, 41-67, doi:10.1007/s10584-009-9724-x, 2010.

Büntgen, U., Esper, J., Frank, D. C., Nicolussi, K., and Schmidhalter, M.: A 1052-year tree-ring proxy for Alpine summer temperatures, Clim. Dynam., 25, 141-153, 2005.

Büntgen, U., Frank, D. C., Nievergelt, D., and Esper, J.: Summer temperature variations in the European Alps, AD 755-2004, J. Climate, 19, 5606-5623, 2006.

Büntgen, U., Trouet, V., Frank, D., Leuschner, H. H., Friedrichs, D., Luterbacher, J., and Esper, J.: Tree-ring indicators of German summer drought over the last millennium, Quaternary Sci. Rev. 29, 1005-1016, 2010.

Büntgen, U., Brázdil, R., Dobrovolný, P., Trnka, M., and Kyncl, T.: Five centuries of Southern Moravian drought variations revealed from living and historic tree rings, Theor. Appl. Climatol., 105, 167-180, doi:10.1007/s00704-010-0373-9, 2011a.

Büntgen, U., Brázdil, R., Heussner, K. U., Hofmann, J., Kontic, R., Kyncl, T., Pfister, C., Chromá, K., and Tegel, W.: Combined dendro-documentary evidence of Central European hydroclimatic springtime extremes over the last millennium, Quaternary Sci. Rev. 30, 3947-3959, doi:10.1016/j.quascirev.2011.10.010, 2011b.

Büntgen, U., Tegel, W., Nicolussi, K., McCormick, M., Frank, D., Trouet, V., Kaplan, J. O., Herzig, F., Heussner, K. U., Wanner, H., Luterbacher, J., and Esper, J.: 2500 years of European climate variability and human susceptibility, Science, 331, 578583, doi:10.1126/science.1197175, 2011c.

Cedro, A.: Tree-ring chronologies of downy oak (Quercus pubescens) pedunculate oak ( $Q$. robur) and sessile oak $(Q$. petraea) in the Bielinek Nature Reserve: comparison of the climatic determinats of tree-ring width, Geochronometria, 26, 2945, doi:10.2478/v10003-007-0005-2, 2007.

Chytrý, M., Kučera, T., and Kočí, M.: Katalog biotopů České republiky (Catalogue of Biotopes of the Czech Republic). Agentůra ochrany přírody a krajiny ČR, Praha, 307 pp., 2001.

Ciais, P., Reichstein, M., Viovy, N., Granier, A., Ogee, J., Allard, V., Aubinet, M., Buchmann, N., Bernhofer, C., Carrara, A., Chevallier, F., De Noblet, N., Friend, A. D., Friedlingstein, P., Grunwald, T., Heinesch, B., Keronen, P., Knohl, A., Krinner, G., Loustau, D., Manca, G., Matteucci, G., Miglietta, F., Ourcival, J. M., Papale, D., Pilegaard, K., Rambal, S., Seufert, G., Soussana, J. F., Sanz, M. J., Schulze. E. D., Vesala, T., and Valentini, R.: Europe-wide reduction in primary productivity cause by the heat and drought in 2003, Nature, 437, 529-533, 2005. 
Coles, S.: An introduction to statistical modeling of extreme values, Springer-Verlag, London, 208 pp., 2001.

Cook, E. R.: A time series analysis approach to tree-ring standardization, $\mathrm{PhD}$ dissertation, University of Arizona, Tucson, 171 pp., 1985.

Cook, E. R. and Krusic, P. J.: ARSTAN v. 41d: A Tree-ring Standardization Program Based on Detrending and Autoregressive Time Series Modeling, with Interactive Graphics, Tree-Ring Laboratory, Lamont-Doherty Earth Observatory of Columbia University, Palisades, New York, USA, http://www. ldeo.columbia.edu/tree-ring-laboratory/resources/software (last access: 20 June 2015), 2005.

Cook, E. R. and Peters, K.: The smoothing spline: a new approach to standardizing forest interior tree-ring width series for dendroclimatic studies, Tree-Ring Bulletin, 41, 45-53, 1981.

Cook, E. R. and Peters, K.: Calculating unbiased tree-ring indices for the study of climatic and environmental change, Holocene, 7 , 361-370, 1997.

Cook, E. R., Briffa, K. R., Meko, D. M., Graybill, D. A., and Funkhouser, G.: The segment length curse in long tree-ring chronology development for palaeoclimatic studies, Holocene, 5, 229-237, 1995.

Cooper, R. J., Melvin, T. M., Tyers, I., Wilson, R. J. S., and Briffa, K. R.: A tree-ring reconstruction of East Anglian (UK) hydroclimate variability over the last millennium, Clim. Dynam., 40, 1019-1039, 2013.

D’Arrigo, R., Wilson, R., Liepert, B., and Cherubini, P.: On the 'Divergence Problem' in Northern Forests: A review of the tree-ring evidence and possible causes, Global Planet. Change, 60, 289305, 2008.

Dobrovolný, P., Moberg, A., Brázdil, R., Pfister, C., Glaser, R., Wilson, R., van Engelen, A., Limanówka, D., Kiss, A., Halíčková, M., Macková, J., Riemann, D., Luterbacher, J., and Böhm, R.: Monthly and seasonal temperature reconstructions for Central Europe derived from documentary evidence and instrumental records since AD 1500, Clim. Change, 101, 69-107, doi:10.1007/s10584-009-9724-x, 2010.

Dobrovolný, P., Brázdil, R., Trnka, M., Kotyza, O., and Valášek, H.: Precipitation reconstruction for the Czech Lands, AD 15012010, Int. J. Climatol., 35, 1-14, doi:10.1002/joc.3957, 2015.

Easterling, D. R., Meehl, G. A., Parmesan, C., Changnon, S. A., Karl, T. R., and Mearns, L. O.: Climate extremes: Observations, modeling, and impacts, Science, 289, 2068-2074, 2000.

Eckstein, D. and Bauch, J.: Beitrag zur Rationalisierung eines dendrochronologischen Verfahrens und zur Analyse seiner Aussagesicherheit, Forstwiss, Centralblatt, 88, 230-250, 1969.

Ferro, C. A. T. and Segers, J.: Inference for clusters of extreme values, Journal of Royal Statistical Society B, 65, 545-556, 2003.

Fischer, E. M., Beyerle, U., and Knutti, R.: Robust spatially aggregated projections of climate extremes, Nature Climate Change, 3, 1033-1038, doi:10.1038/nclimate2051, 2013.

Frank, D. C., Büntgen, U., Böhm, R., Maugeri, M., and Esper, J.: Warmer early instrumental measurements versus colder reconstructed temperatures: Shooting at a moving target, Quaternary Sci. Rev., 26, 3298-3310, 2007.

Friedrich, M., Remmele, S., Kromer, B., Hofmann, J., Spurk, M., Kaiser, K.F., Orcel, C., and Küppers, M.: The 12,460-year Hohenheim oak and pine tree-ring chronology from Central Europe - a unique annual record for radiocarbon calibration and paleoenvironment reconstructions, Radiocarbon, 46, 1111-1122, doi:10.2458/azu_js_rc.46.4172, 2004.

Friedrichs, D., Büntgen, U., Esper, J., Frank, D., Neuwirth, B., and Löffler, J.: Complex climate controls on 20th century oak growth in Central-West Germany, Tree Physiol., 29, 39-51, doi:10.1093/treephys/tpn003, 2009.

Gea-Izquierdo, G., Cherubini, P., and Cañellas, I.: Tree-rings reflect the impact of climate change on Quercus ilex L. along a temperature gradient in Spain over the last 100 years, Forest Ecol. Manag., 262, 1807-1816, 2011.

Glaser, R.: Klimageschichte Mitteleuropas, 1200 Jahre Wetter, Klima, Katastrophen, Primus Verlag, Darmstadt, 264 pp., 2008.

Groisman, P. Y., Knight, R. W., Easterling, D. R., Karl, T. R., Hegerl, G. C., and Razuvaev, V. A. N.: Trends in intense precipitation in the climate record, J. Climate, 18, 1326-1350, 2005.

Huntington, T. G.: Evidence for intensification of the global water cycle: Review and synthesis, J. Hydrol., 319, 83-95, 2006.

IPCC, Climate Change 2013: The Physical Science Basis. Contribution of Working Group I to the Fifth Assessment Report of the Intergovernmental Panel on Climate Change, edited by: Stocker, T. F., Qin, D., Plattner, G. K., Tignor, M., Allen, S. K., Boschung, J., Nauels, A., Xia, Y., Bex, V., and Midgley, P. M., Cambridge University Press, Cambridge, United Kingdom and New York, NY, USA, 1535 pp., 2013.

Jolly, W. M., Dobbertin, M., Zimmermann, N. E., and Reichstein, M.: Divergent vegetation growth responses to the 2003 heat wave in the Swiss Alps, Geophys. Res. Lett., 32, L18409, doi:10.1029/2005GL023252, 2005.

Jones, P. D.: Early European instrumental record, in: History and climate: memories of the future?, edited by: Jones, P. D., Ogilvie, A. E. J., Davies, T. D., and Briffa, K., Kluwer Academic Press, New York, 55-77, 2001.

Jones, P. D., Briffa, K. R., Osborn, T. J., Lough, J. M., van Ommen, T. D,, Vinther, B. M., Luterbacher, J., Wahl, E. R., Zwiers, F. W., Mann, M. E., Schmidt, G. A., Ammann, C. M., Buckley, B. M., Cobb, K. M., Esper, J., Goosse, H., Graham, N., Jansen, E., Kiefer, T., Kull, C., Küttel, M., Mosley-Thompson, E., Overpeck, J. T., Riedwyl, N., Schulz, M., Tudhope, A. W., Villalba, R., Wanner, H., Wolff, E., and Xoplaki, E.: High-resolution paleoclimatology of the last millennium: a review of current status and future prospects, Holocene, 19, 3-49, 2009.

Kern, Z., Grynaeus, A., and Morgos, A.: Reconstructed precipitation for southern Bakony Mountains (Transdanubia, Hungary) back to $1746 \mathrm{AD}$ based on ring widths of oak trees, Idojaras, 113, 299-314, 2009.

Knapp, A. K., Beier, C., Briske, D. D., Classen, A. T., Luo, Y., Reichstein, M., Smith, M. D., Smith, S. E., Bell, J. E., and Fay, P. A.: Consequences of more extreme precipitation regimes for terrestrial ecosystems, Bioscience, 58, 811-821, 2008.

Kolář, T., Kyncl, T., and Rybníček, M.: Oak chronology development in the Czech Republic and its teleconnection on a European scale, Dendrochronologia, 30, 243-248, 2012.

Lloyd, A. H., Duffy, P. A., and Mann, D. H.: Nonlinear responses of white spruce growth to climate variability in interior Alaska, Can. J. Forest Res., 43, 331-343, 2013.

Luterbacher, J., Xoplaki, E., Dietrich, D., Rickli, R., Jacobeit, J., Beck, C., Gyalistras, D., Schmutz, C., and Wanner, H.: Reconstruction of sea level pressure fields over the eastern North At- 
lantic and Europe back to 1500 , Clim. Dynam., 18, 545-561, 2002.

Mailier, P. J., Stephenson, D. B., and Ferro, C. A. T.: Serial clustering of extratropical cyclones, Mon. Weather Rev., 134, 22242240, 2006.

Min, S. K., Zhang, X., Zwiers, F. W., and Hegerl, G. C.: Human contribution to more-intense precipitation extremes, Nature, 470, 378-381, doi:10.1038/nature09763, 2011.

Morin, X., Roy, J., Sonie, L., and Chuine, I.: Changes in leaf phenology of three European oak species in response to experimental climate change, New Phytol., 186, 900-910, 2010.

Opala, M.: The 443-Year Tree-Ring Chronology for the Scots Pine from Upper Silesia (Poland) as A Dating Tool and Climate Proxy, Geochronometria, 42, 41-52, doi:10.1515/geochr-20150005, 2015.

Opala, M. and Mendecki M. J.: An attempt to dendroclimatic reconstruction of winter temperature based on multispecies treering widths and extreme years chronologies (example of Upper Silesia, Southern Poland), Theor. Appl. Climatol., 115, 73-89, doi:10.1007/s00704-013-0865-5, 2014.

Osborn, T. J., Briffa, K. B., and Jones, P. D.: Adjusting variance for sample size in tree-ring chronologies and other regional mean timeseries, Dendrochronologia, 15, 89-99, 1997.

Pfister, C.: Wetternachhersage, 500 Jahre Klimavariationen und Naturkatastrophen (1496-1995), Verlag Paul Haupt, Bern, Stuttgart, Wien, 304 pp., 1999.

Rammig, A., Wiedermann, M., Donges, J. F., Babst, F., von Bloh, W., Frank, D., Thonicke, K., and Mahecha, M. D.: Coincidences of climate extremes and anomalous vegetation responses: comparing tree ring patterns to simulated productivity, Biogeosciences, 12, 373-385, doi:10.5194/bg-12-373-2015, 2015.

Reyer, C. P. O., Leuzinger, S., Rammig, A., Wolf, A., Bartholomeus, R. P., Bonfante, A., De Lorenzi, F., Dury, M., Gloning, P., Abou Jaoudé, R., Klein, T., Kuster, T. M., Martins, M., Niedrist, G., Riccardi, M., Wohlfahrt, G., De Angelis, P., de Dato, G., François, L., Menzel, A., and Pereira, M.: A plant's perspective of extremes: Terrestrial plant responses to changing climatic variability, Global Change Biol., 19, 75-89, 2012.

Rohr, C.: Extreme Naturereignisse im Ostalpenraum. Naturerfahrung im Spätmittelalter und am Beginn der Neuzeit, Böhlau Verlag, Köln, Weimar, Wien, 640 pp., 2007.

Roth, M., Buishand, T. A., Jongbloed, G., Klein Tank, A. M. G., and van Zanten, J. H.: Projections of precipitation extremes based on a regional, non-stationary peaks-over-threshold approach: A case study for the Netherlands and north-western Germany, Weather and Climate Extremes, 4, 1-10, doi:10.1016/j.wace.2014.01.001, 2014.

Rybníček, M., Čermák, P., Prokop, O., Žid, T., Trnka, M., and Kolář, T.: Oak (Quercus spp.) response to climate differs more among sites than among species in central Czech Republic, Dendrobiology, in review, 2015a.

Rybníček, M., Čermák, M., Žid, P., Kolář, T., Trnka, M., and Büntgen, U.: Exploring Growth Variability and Crown Vitality of Sessile Oak (Quercus petraea) in the Czech Republic, Geochronometria, 42, 17-27, doi:10.1515/geochr-2015-0003, 2015b.
Rydval, M. and Wilson, R.: The Impact of Industrial SO2 Pollution on North Bohemia Conifers, Water Air Soil Pollut., 223, 57275744, doi:10.1007/s11270-012-1310-6, 2012.

Schär, C., Vidale, P. L., Lüthi, D., Frei, C., Häberli, C., Liniger, M. A., and Appenzeller, C.: The role of increasing temperature variability in European summer heatwaves, Nature, 427, 332336, 2004.

Schoch, W., Heller, I., Schweingruber, F. H., and Kienast, F.: Wood anatomy of central European Species, online version, http:www. woodanatomy.ch (last access: 20 June 2015), 2004.

Tegel, W., Vanmoerkerke, J., and Büntgen, U.: Updating historical tree-ring records for climate reconstruction, Quaternary Sci. Rev., 29, 1957-1959, 2010.

Trachsel, M., Kamenik, C., Grosjean, M., McCarrol, D., Moberg, A., Brázdil, R., Büntgen, U., Dobrovolný, P., Esper, J., Frank, D. C., Friedrich, M., Glaser, R., Larocque-Tobler, I., Nicolussi, K., and Riemann, D.: Multi-archive summer temperature reconstruction for the European Alps, AD 1053-1996, Quaternary Sci. Rev., 46, 66-79, doi:10.1016/j.quascirev.2012.04.021, 2012.

Ulbrich, U., Brücher, T., Fink, A., Leckebusch, G., Krüger, A., and Pinto, J.: The central European floods in August 2002. Part I: rainfall periods and flood development, Weather, 58, 371-376, $2003 a$.

Ulbrich, U., Brücher, T., Fink, A., Leckebusch, G., Krüger, A., and Pinto, J.: The central European floods in August 2002. Part II: synoptic causes and considerations with respect to climate change, Weather, 58, 434-441, 2003b.

Villarini, G., Smith, J. A., Baeck, M. L., Vitolo, R., Stephenson, D. B., and Krajewski, W. F.: On the frequency of heavy rainfall for the Midwest of the United States, J. Hydrol., 400, 103-120, 2011.

Wetter, O. and Pfister, C.: An underestimated record breaking event - why summer 1540 was likely warmer than 2003, Clim. Past, 9 , 41-56, doi:10.5194/cp-9-41-2013, 2013.

Wigley, T. M. L., Briffa, K. R., and Jones, P. D.: On the average value of correlated time series, with applications in dendroclimatology and hydrometeorology, J. Appl. Meteorol. Clim., 23, 201-213, doi:10.1175/1520-0450(1984)023< 0201:OTAVOC〉 2.0.CO;2, 1984.

Wilson, R., Miles, D., Loader, N. J., Melvin, T., Cunningham, L., Cooper, R., and Briffa, K.: A millennial long March-July precipitation reconstruction for southern-central England, Clim. Dynam., 40, 997-1017, doi:10.1007/s00382-012-1318-z, 2013.

Wilson, R. J. S., Luckman, B. H., and Esper, J.: A 500 year dendroclimatic reconstruction of spring-summer precipitation from the lower Bavarian Forest region, Germany, Int. J. Climatol., 25, 611-630, 2005.

Zhang, X., Zwiers, F. W., Hegerl, G. C., Lambert, F. H., Gillett, N. P., Solomon, S., Stott, P. A., and Nozawa. T.: Detection of human influence on twentieth-century precipitation trends, Nature, 448, 461-465, 2007. 